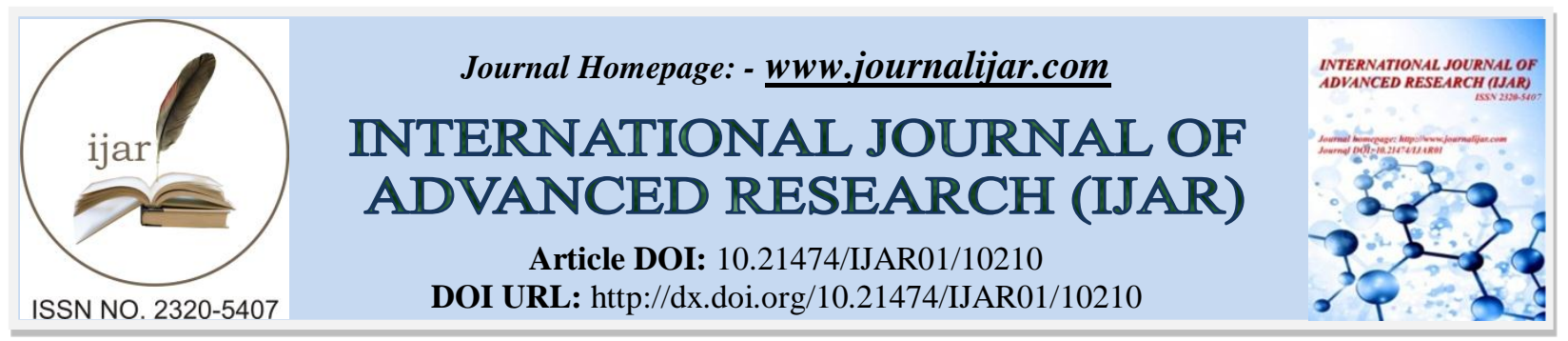

RESEARCH ARTICLE

\title{
THE ROLE OF ENGLISH IDIOMS IN TEACHING ENGLISH
}

Azizova Gulnoza Ganijanovna

Doctor of Philosophy in Pedagogy (PhD), Samarkand State Institute of Foreign Languages, Uzbekistan.

\section{Manuscript Info}

\section{Manuscript History}

Received: 10 October 2019

Final Accepted: 12 November 2019

Published: December 2019

Key words:-

Idiom, English, Teaching Foreign

Languages, Uzbek

\section{Abstract}

This article discusses the role of English idioms in teaching English. Many comparisons are given of the idioms of the English and Uzbek languages. In addition, the role of teaching idioms in the development of language competence of students of language universities is touched upon.

\section{Introduction:-}

In recent years, there has been a significant development of linguistic relations between the Uzbek and English languages, as well as the direct and indirect influence of the English language on the Uzbek language. The main feature of this language situation is that young people in the country really want to learn English, and English acts as a means of exchanging information along with Uzbek.

The fact that cultural, social and economic ties with foreign countries are growing from year to year further strengthens the position of the English language. Today, the English language is developing as a language of communication, which provides an opportunity for dialogue between peoples and countries. Accordingly, over the past twenty years, many different phrases and words have entered the Uzbek language from English, which can be widely used even if the ordinary population does not know about their origin. For example, it is advisable to divide words and phrases from English into Uzbek into economic, cultural and technological groups:

\section{Economic Terms:-}

offshore, (off-shore) offshore money, offshore zone in the meaning of "free", from the English. off-shore "offshore, on the high seas"

dumping - "decrease", from the English. damping, one of the meanings of which is "jamming, braking"

\section{Political terms:-}

Speaker - Speaker of the Parliament, from English speaker - "speaker", as well as "chairman of the House of Commons in England and the House of Representatives in the USA"; inauguration - "the ceremony of assuming office of the president of the country", from English inauguration "taking office"; rating - "rating", from the English rating "rating, assignment to a particular class, category."

\section{Technological terms:-}

roaming - "distribution; the possibility of widespread use ", from the English. to roam "to wander" ("Roaming around the world", from the advertisement of mobile phones on TV). site - from English. site "location"; file - from English file "registrar; dossier, case; submission of document" and others.

\section{Corresponding Author:- Azizova Gulnoza Ganijanovna}

Address:- Doctor of Philosophy in Pedagogy (PhD), Samarkand State Institute of Foreign Languages, Uzbekistan. 


\section{Household supplies:-}

mixer - from the English mixer "mixing apparatus or device";

toaster - from the English toaster "device for toasting toasts" (from toast "toasted bread slice, toast");

roster - from the English roaster - "roasting pan" (from to roast "fry");

shaker - from the English shaker "vessel for making cocktails" (from to shake "shake"), etc.

\section{Sport Terms:-}

bowling - a game in which a ball thrown on the floor must knock down skittles standing in a group, from English bowl "bowl; bowling"; diving - "scuba diving", from the English to dive "to dive, dive into the water" (from here the diver is "a scuba diver, diver"); skateboard - "riding on a board with rollers", from the English skate "ice skating, gliding" and board; snowboard - "riding on a board in the snow", from the English snow "snow" and board; snowblade - "skiing in the snow on the largest size of stunt skiing", from the English snowblade "stunt skiing"; biker - a cyclist; motorcyclist ", from the English bike - abbrev., decomp. from bicycle; shaping - from the English shaping (from to shape); fitness - from the English fitness - "conformity" (from to be fit, "conform, be fit", etc.

\section{Terms of modern music:-}

hit - "popular song", from the English. hit one of the meanings of which is "success, luck" ("and what is not in his hits of nerve, strain and other energy catalysts is the lot of others", "world of news"); single - "song, recorded separately", from the English single - "one, only" ("sound existing by separate singles"); remake - "remake", from the English remake in the same meaning ("Evgeny Popov wrote a remake of the Turgenevsky novel" The Eve "); image - from the English image "image" ("In his past programs was adequate to his image", "World is new.");

\section{Movie terms:-}

blockbuster - "sensation; a film that is very popular, "from English block-buster, the original meaning of which is a "high-explosive large-caliber bomb" ("Today one of the main blockbusters of the year comes out on the screens of Russian cinemas - the film "Izgoy"); design - from the English design "design, plan; construction " ("The tabletop roaster "fondue" is distinguished by a rather clumsy design"); poster - "a small poster depicting an artist", from the English poster"

\section{Cosmetology Terms:-}

lifting - "lift", from the English lifting "lifting"; peeling - "face cleansing", from English peeling "peeling" from to peel "peeling, peel off; scrub - "cream for exfoliation, skin cleansing", from the English to scrub - "scratch", etc.

These situations, that is, the growing status of the English language, require a deeper knowledge of English among students, the organization of a comprehensive process of understanding it. One of the areas requiring such special study is the English idioms.

English vocabulary is unique, and its structure and composition are rich and diverse. One of the unique features of the English language is the English idioms. Many English idioms have switched to other languages, which are now reformulated and introduced into the circulation of the general public both in spoken language and in literary language.

The idioms in English are very wide and deeply absorbed in the richness of the language, it is very difficult to imagine English without idioms. Idioms are a very common linguistic phenomenon, especially in spoken language, as well as in fiction. If you do not know idioms, you will not be able to understand many phrases and turns and find out what they mean. Accordingly, it cannot be said that we mastered the English language without mastering the idioms.

Since words in an idiom unite in a holistic linguistic organism, they lose their original semantic meaning, therefore, when they unite in an idiom, they lose their original meaning and acquire a completely new meaning. And this new meaning will apply not only to the combined meaning, which is the sum of the values of a particular set of words, but also to a specific holistic new meaning. In most cases, this alternation will be based on a change in the semantics of vocabulary or the acquisition of a new meaning in a complex of words in idioms. For example, "Close, but no

cigar!” - literal translation - "Ёпинг, аммо сигаретага ўрин йўқ!” - original meaning - "Унчалик тўғри эмас, Хисобга ўтмайди”. 
Therefore, idioms cannot be directly translated as phrases, that is, based on the sum of the meanings of the words included in the idiom. When translating idioms, it will be possible to adequately explain the meaning of this complex of words, that is, on the basis of what they are given a holistic meaning that arises on the basis of their structural unit, which is far from the individual meaning of the words. The semantics of an idiom is not a simple sum of words included in it, because idioms do not consist of linguistic "free" or "independent" units, but rather of "free" words that "use their will to create idioms". For example, "It's raining cats and dogs" - literal translation - "Мушук ва кучуклардан ёмғир ёғяпти", original meaning - “Осмондан сув қуйиляпти. Роса ёмzир қуйяпти”.

An idiom is the special meaning of words that do not repeat the meaning of their generalization, which are units of speech. Idioms are classified as general linguistic phenomena, divided into specific linguistic and interlanguage idioms.

Obviously, idioms provide a lot of material for the richness of the language, the meaning of the language and its complex structure. When students often encounter such linguistic features, phraseological units, they cannot always translate them correctly, directly, using dictionaries. To work with English idioms and to adequately and equivalently understand their meaning, students need to develop some knowledge, skills and abilities related to idioms, their semantics, their specific linguistic and semantic structures. Since, on the one hand, idioms are combined with the unique nature of the English language, on the other hand, its structure and meaning of static expressions are unique, and their understanding and interpretation cannot be used literally.

Currently, for the development of the country's economy, it is necessary to train developed, creative, competent, motivated, well-educated personnel. The quality of the educational process, its provision with modern knowledge and its continuous improvement of the content are necessary to complete this task. It is necessary to provide students with extensive and deep knowledge about idioms, that is, about the content of stable phraseological compounds, their essence, etymology and translations in the process of teaching English.

For example, "Hot Dog!" "Wow", "OK”, "Coffee break", "Know how", "Goal keeper" today is widely used in English. Such phrases are now used directly in many languages of the world, but many do not know the basics of how they are formed, their historical origin and content.

At the same time, the issue of translating English idioms into Uzbek is of great interest. Consequently, students will be able to more accurately and adequately understand linguistic expressions, explaining the various expressions commonly used in foreign countries.

Today, students must constantly improve their language skills, ensure that modern students are ready for such an interstate dialogue in the context of growing international and regional cooperation, and constantly update their linguistic knowledge, skills and abilities. And the study of English idioms is tantamount to the same goal, that is, a deep knowledge and understanding of the English language.

It will consist of phased training of students in English idioms, directing them from simple to complex, first introducing the meaning and linguistic characteristics of individual idioms, and then helping them find idioms in the literary text and master the skills of adequate and equivalent translation. Because idioms cannot be translated verbatim. After determining the meaning of the idiom, a stable phrase is searched in the Uzbek language, equivalent to it. It can be selected for translation only if the static expression in the Uzbek language gives the meaning of the English idiom.

\section{Literature:-}

Gulnoza Azizova. Theory and practice of innovative pedagogical activity of teachers of higher education (on the example of the activity of teachers of the English language): the dissertation of the candidate of pedagogical sciences: 13.00.01 .. Tashkent, 2015. 